\title{
The Financial Precision Poverty Alleviation in Heilongjiang Province
}

\author{
Yutian Yang * \\ School of Economics and Management, Beijing Jiaotong University, Beijing, China \\ *Corresponding author. Email:2860914420@qq.com
}

\begin{abstract}
In 2013, General Secretary Xi Jinping first proposed the concept of "precise poverty alleviation" during an investigation in Xiangxi, Hunan. After that, China successively introduced many relevant policies, coordinated arrangements and gradually carried out targeted poverty alleviation work in order to achieve poverty eradication and improvement. The living standards of the broad masses of people, the revitalization of rural areas in our country, and the gradual realization of the beautiful vision of common prosperity. Targeted poverty alleviation has gradually become an important strategy implemented in China's poverty alleviation work, and has achieved remarkable results. By the end of 2020, about 100 million poor people in rural areas in China have all been lifted out of poverty, and 832 impoverished counties have achieved it. Taking off the hat, so far China has basically completed the work of poverty alleviation. This article takes the development of financial precision poverty alleviation in rural poverty-stricken areas in China's Heilongjiang Province as an example, and combines several theories in this area, analyzes the existing problems, and proposes targeted development countermeasures to promote the economic development of Heilongjiang Province.
\end{abstract}

Keywords: Precision poverty alleviation, Rural finance, Shake off poverty

\section{THE PURPOSE AND SIGNIFICANCE OF THIS ARTICLE}

\subsection{Purpose}

This article takes Heilongjiang's rural financial targeted poverty alleviation as the research object, analyzes the current financial targeted poverty alleviation work in rural areas of Heilongjiang Province, and analyzes some of the problems and shortcomings in the implementation of targeted poverty alleviation policies in Heilongjiang Province. Based on the reasons for these problems, we put forward constructive countermeasures that can improve the current situation of Heilongjiang Province's financial precision poverty alleviation, hoping to improve the quality of Heilongjiang Province's financial precision poverty alleviation, and help farmers in poverty-stricken areas in Heilongjiang to get rid of poverty. It is also possible to eliminate poverty, ensure that poverty is truly eliminated, and improve the living standards of farmers.

\subsection{Significance}

\subsubsection{Theoretical Meaning}

Precision poverty alleviation is an important means to help farmers get rid of poverty. In the process of researching its theoretical foundation, this article enriches the theoretical knowledge of precision poverty alleviation and finance related to a certain extent based on the relationship between finance and precision poverty alleviation. This article is also dedicated to exploring the role of finance in helping poverty-stricken areas to get rid of poverty, exploring how to make full use of the role of finance, and further improving related research on targeted poverty alleviation by means of finance based on the research results of existing scholars. The results have also diversified the existing precision poverty alleviation methods.

\subsubsection{Realistic Meaning}

The practical significance of this article is to summarize the overall current situation of Heilongjiang 
Province's targeted poverty alleviation by financial means, analyze the problems of Heilongjiang Province in targeted financial poverty alleviation, and use this as a basis to summarize how to improve the level of targeted poverty alleviation through financial means. What we need to do is giving full play to the role of finance, increasing the proportion of financial poverty alleviation in the targeted poverty alleviation methods in rural areas of Heilongjiang Province, finding out the most suitable method for poverty alleviation of the poor in rural areas of Heilongjiang Province, and making the poverty alleviation work efficient.

\section{IMPLEMENTATION STATUS OF TARGETED POVERTY ALLEVIATION BY RURAL FINANCE IN HEILONGJIANG PROVINCE}

\subsection{The Construction of Poverty Alleviation Facilities Is Improving Day by Day}

Heilongjiang Province has invested a large amount of funds in the construction of water supply and power supply systems, rural roads, and communication networks in rural areas, creating a good external condition for the development of financial precision poverty alleviation. Heilongjiang Provincial Department of Housing and Urban-Rural Development has also increased the Renovation efforts, distribution of dilapidated house renovation subsidy funds, help poor households to repair and renovate dilapidated houses, and create a good living condition for farmers, the Poverty Alleviation Office also keeps pace with the times, conforms to the development of the times, and promptly leads e-commerce into the countryside to make full use of The Internet has built an effective agricultural product network sales platform, which links the supply market and demand market of agricultural products to solve sales problems.

\subsection{Continuous Innovation in Poverty Alleviation Methods}

In the process of carrying out financial targeted poverty alleviation, Heilongjiang Province has successively issued a number of documents. The introduction of these financial targeted poverty alleviation policies is an innovation of the original policies, including the full popularization of microfinance in rural areas and the introduction of agricultural insurance into rural areas. The establishment of markets and poverty alleviation funds in rural areas, etc. In order to ensure that all poverty alleviation funds are used for the development and construction of rural areas, the government strictly prohibits microfinance loans to enterprises for use, and must use all these funds for the purpose of helping poor households get rid of poverty. In addition, Heilongjiang Province is implementing financial targeted poverty alleviation In the course of the policy, we also paid attention to the investigation and punishment of violations of regulations and disciplines, proactively avoided the emergence of problems that harm the interests of poor households, and actively implemented and supervised the development of poverty alleviation projects. With the efforts of the Poverty Alleviation Office and other relevant departments, the effect of financial poverty alleviation has been significantly improved.

\subsection{Remarkable Results Have Been Achieved in Poverty Alleviation}

Heilongjiang Province has achieved good results in both the speed and quality of targeted poverty alleviation since the launch of targeted financial poverty alleviation work. Up to now, Heilongjiang Province has won the difficult battle of poverty alleviation and achieved the great goal of all the more than 100,000 poor people in the province. The poverty-stricken counties in the province have also taken off the "poverty" label. The focus of work has also changed to equal emphasis on poverty alleviation and consolidation, instead of focusing on poverty alleviation before. In terms of the quality of precision poverty alleviation, the poverty alleviation work in Heilongjiang Province has always focused on people who are at risk of returning to poverty, through dynamic detection, and timely targeted assistance. To prevent them from returning to poverty and to ensure the quality of poverty alleviation, the government also strongly supports poverty alleviation industries and projects. With the help of special funds for poverty alleviation, these industries have good development prospects and stable income.

\section{CAUSES OF PROBLEMS IN HEILONGJIANG PROVINCE'S RURAL FINANCIAL TARGETED POVERTY ALLEVIATION}

\subsection{Natural causes in Rural Areas of Heilongjiang Province}

Heilongjiang Province is a plain area with cold weather and short crop growth cycle. Compared with other regions, the production cost is higher. Moreover, due to the weather in Heilongjiang Province, natural disasters occur frequently. It has caused great harm to the agricultural product planting industry, ranging from reduced production and volume. And brought great instability to the agricultural income of poor households, resulting in a large amount of poverty alleviation funds used to maintain the basic life of poor 
households. The use efficiency is greatly reduced. On the other hand, there is a single variety of agricultural products that can be grown in rural areas of Heilongjiang Province, mainly corn and rice. In the hail and frost weather, the output will be greatly reduced, leading to a sharp drop in farmers' income and falling into a vicious circle of poverty.

\subsection{Financial Poverty Alleviation Is Difficult to Form a Virtuous Circle}

Most of the rural areas in Heilongjiang Province have the problem of imperfect infrastructure construction, and financial supporting facilities are even rarer. This makes it difficult to maintain the diversity of financial services in poverty alleviation, which causes financial institutions to carry out targeted poverty alleviation. When working, there will be a problem, that is, because the available supporting facilities for poverty alleviation are not perfect, it is often impossible to implement poverty alleviation policies in the first time, making it more difficult for poverty alleviation. How can we make efficient and targeted poverty alleviation work become a reality? In addition, the overall income level of Heilongjiang Province is relatively low. Farmers in poverty-stricken areas have less income on this basis. After their daily expenses, they rarely have a surplus, which means that they will hardly have extra funds to deposit in banks, etc. Financial institutions, the possibility of financial institutions absorbing funds in rural areas is almost non-existent, and farmers' ability to repay funds is poor, which makes financial institutions unwilling to provide financial support to poor areas, which hinders the development of the local economy. Affect the efficiency of targeted poverty alleviation.

\subsection{Lack of Incentives and Constraints On Financial Institutions Participating in Poverty Alleviation}

In poverty-stricken areas, although large financial institutions dominated by commercial banks have successively carried out a series of poverty alleviation work in poverty-stricken areas, they are all enterprises whose core is the pursuit of profit maximization. The implementation of poverty alleviation policies is only to fulfill the requirements of the government. Banks and other financial institutions will not invest high-quality resources in rural areas, and increase investment in poor areas, which may result in profits less than costs and cause bank losses. Therefore, banks and other financial institutions are more willing to choose customers with high practical value for investment. In response to this situation, the government and relevant financial departments will issue some incentive policies to encourage banks and other financial institutions to invest in poverty-stricken areas, but most of these policies have not been implemented. They only stay at the policy level and lack legal constraints. The enthusiasm of financial institutions to participate in poverty alleviation is not high. If the government and poverty alleviation-related institutions cannot issue incentive policies and implement them carefully, then financial institutions, including commercial banks, whose business objectives are profit maximization, will not invest a lot of experience in working in povertystricken areas, resulting in low poverty alleviation efficiency.

\subsection{Financial Institutions Involved in Poverty Alleviation Cannot Play a Synergistic Role}

In the poverty-stricken areas of Heilongjiang Province, state-owned commercial banks such as the Agricultural Bank of China, and local commercial banks such as Heilongjiang Bank have branches in rural areas. There is no exchange and cooperation between each other, and funds are provided to reputable customers during poverty alleviation. Really poor farmers rarely get help, and financial institutions have not played the role of real poverty alleviation and cannot truly solve the problem. In addition, non-bank financial institutions cannot cooperate with each other to play a role. Take insurance companies as an example. Natural disasters occur frequently in rural areas in Heilongjiang Province, and support from insurance companies is needed. In fact, insurance companies provide services in these areas. There are few types of insurance, and the coverage rate of agricultural insurance is relatively low. A large number of farmers and enterprises are not covered by insurance. Once a natural disaster is encountered, the income of farmers will drop significantly, making the effect of poverty alleviation greatly reduced.

\section{DEVELOPMENT COUNTERMEASURES OF TARGETED POVERTY ALLEVIATION IN RURAL FINANCE IN HEILONGJIANG PROVINCE}

\subsection{Raise the Awareness of Various Entities on Targeted Financial Poverty Alleviation}

To raise the awareness of various entities on targeted financial poverty alleviation, it is necessary to start from both the government and financial institutions. The government should increase the proportion of funds allocated to education in poverty-stricken areas, and improve the financial literacy of poor households at the ideological level. Therefore, the first thing the government needs to do is to increase education expenditures in poverty-stricken areas and increase enrollment rates. At the same time, it must also work hard to improve the treatment of rural teachers, attract high-quality teachers to rural areas, improve the overall 
level of rural teachers, and increase farmers' benefits. The quality of education. At the same time, we must also vigorously promote financial targeted poverty alleviation, let local farmers understand the benefits and advantages of financial poverty alleviation, actively cooperate with policies, accept financial targeted poverty alleviation from the psychological level, and let financial targeted poverty alleviation penetrate all aspects of people's lives. Financial institutions must proceed from their own perspective and change their poverty alleviation concepts. They must not follow the old fashioned ways, and must continue to innovate their poverty alleviation thinking. They must not blindly follow the old ideas and methods before and perfunctory. Financial institutions must also have an overall view and realize that targeted poverty alleviation is not only a political task, but also a policy conducive to the long-term development of financial institutions. Only in this way can we give full play to the role of financial institutions in targeted poverty alleviation and promote the economic development of poverty-stricken areas in Heilongjiang Province and the improvement of farmers' living standards.

\subsection{Increase the Effective Supply of Financial Targeted Poverty Alleviation}

To improve the efficiency of rural financial targeted poverty alleviation, we must find ways to increase the effective supply of targeted financial poverty alleviation, which can be specifically considered from the following two aspects. First, the government has issued some assistance policies to actively provide financial institutions with certain support and guide financial institutions to allocate more financial resources to rural areas. At the same time, they must also increase financial support for trusts, funds, insurance and other businesses. They cooperate with banking financial institutions and play a joint role to provide guarantee for targeted financial poverty alleviation. Second, we must vigorously innovate financial products in the poverty alleviation work. We must not blindly follow the old poverty alleviation methods and strategies. We must continue to innovate according to the local economic development. It is necessary to continuously innovate financial products and promote new products. It is also necessary to innovate financial services, increase the diversity of financial services, and increase the effective supply of financial targeted poverty alleviation. Financial institutions should also fully communicate with poor households in advance, and do a good job in connection with poverty alleviation business, so that farmers can feel the convenience of financial precision poverty alleviation brought to their lives from the bottom of their hearts.

\subsection{Improve the Financial Ecological Environment in Rural Areas}

The financial ecological environment in rural areas affects the efficiency of financial targeted poverty alleviation. Therefore, in order to ensure the smooth development of financial targeted poverty alleviation, a good financial ecological environment must be established in rural areas, which can be started from the following two aspects. The first is to establish and improve the rural credit system. On the one hand, the government should increase its propaganda efforts in this regard, by holding lectures, issuing leaflets, to carry out credit publicity and education, and strengthen the credit concept and awareness of rural residents. On the other hand, with the help of third-party agencies, it should build credit system as quickly as possible and give the most financial assistance to poor households. Only by adopting this method can a good credit environment be born in rural areas. The smooth implementation of targeted poverty alleviation can be guaranteed. Instead, the guidance work must be done in advance to allow the Agricultural Bank of China and the Agricultural Development Bank of China to play their role in supporting agriculture. The government should actively introduce incentive policies, give preferential policies to the Agricultural Bank, encourage and guide it to increase the volume of business carried out in poor areas, help rural areas develop the economy, and increase farmers' income.

\subsection{Innovation Drives the Construction of a New Model of Poverty Alleviation}

The successful completion of financial targeted poverty alleviation in poverty-stricken areas in Heilongjiang Province depends on the ability to effectively innovate poverty alleviation methods and service models. Specifically, it can be considered from the following two aspects. One is to increase the diversity of poverty alleviation subjects. The povertystricken areas of Heilongjiang Province are subject to many constraints in the process of economic development. Therefore, when carrying out poverty alleviation work, it is necessary to pay attention to the cooperation between financial institutions and the government. And the government needs to issue a series of support policies to cooperate with financial institutions in poverty alleviation work. And set up a special financial poverty alleviation fund to provide guarantee for the smooth development of poverty alleviation work. Through this method, it will inject vitality into the economic development of poor areas and help farmers improve their living standards. The second is to actively innovate financial products and service methods. In recent years, with the rapid development of the Internet, poverty-stricken areas in Heilongjiang Province should also follow the trend of 
the times, seize opportunities, continue to innovate poverty alleviation products and new models of poverty alleviation, and accelerate the economic development of poverty-stricken areas. In the simplest terms, it can promote close cooperation between poverty alleviation agencies and e-commerce platforms, and provide new opportunities for economic development in poor areas. In the process of targeted poverty alleviation, we must make full use of e-commerce platforms to expand agricultural product marketing channels into online and offline channels. The two models increase the types of agricultural products marketing methods, and then increase farmers' income through this method.

\section{CONCLUDING REMARKS}

Targeted financial poverty alleviation is an important means that can help impoverished areas to become well-off as soon as possible, increase the income of local farmers, and help ordinary people live a happy life. As a large agricultural province in China, Heilongjiang Province has many poverty-stricken areas. Therefore, whether the targeted financial poverty alleviation can be successfully completed and whether the living standards of the residents in the province can be improved has important reference significance for other regions. All in all, financial targeted poverty alleviation is a big project, not an overnight task, but an important work related to the well-being of the people. The government and relevant financial institutions rationally use targeted poverty alleviation measures to help poor areas get rid of poverty as soon as possible, improve people's living standards, and promote a virtuous circle of political and economic development in Heilongjiang Province.

\section{REFERENCES}

[1] Cao Mingming, Cao Yi. Research on Precision Poverty Alleviation of Heilongjiang Rural
Financial Institutions from the Perspective of Rural Revitalization. Rural Economy and Technology, 2020.

[2] Wei Dongmei. Research on the Construction of Baoding Rural Financial Comprehensive Service Platform from the Perspective of Targeted Poverty Alleviation. Modern Business Industry, 2019.

[3] $\mathrm{Wu}$ Hao. Research on the Countermeasures of Financial Targeted Poverty Alleviation in Heilongjiang Province. Chinese and Foreign Entrepreneurs, 2019.

[4] Chen Saiping. Research on the Dilemma and Countermeasures of Financial Targeted Poverty Alleviation. Modern Business Industry, 2017.

[5] Han Zhiyuan, Li Yuzhuo, Du Hongyu. Research on Targeted Poverty Alleviation in Finance. Jilin Financial Research, 2018.

[6] Mo Guohuan. Analysis of Information Service Mechanism in the Process of Targeted Poverty Alleviation. Rural Economy and Technology, 2018.

[7] Financial Support and Practical Help Between Older Parents and Their Middle-aged Children in Europe.Christian Deindl,Martina Brandt. Ageing and Society.2010.

[8] Philippe Aghion,Patrick Bolton. A Theory of Trickle-Down Growth and Development. The Review of Economic Studies, 1997.

[9] David Dollar,Aart Kraay. Growth is Good for the Poor. Journal of Economic Growth, 2002.

[10] Alexandra Bernasek. Banking on Social Change: Grameen Bank Lending to Women. International Journal of Politics, Culture and Society,2003. 